\title{
Condom Tamponade in the Management of Massive Obstetric Hemorrhage: An Experience at a Teaching Hospital
}

\author{
Gurung BS ${ }^{1}$, Dongol $\mathbf{Y}^{2}$, Tuladhar $\mathbf{H}^{3}$ \\ ${ }^{1}$ Department of Obstetrics and Gynaecology, KIST Medical College, Lalitpur, Nepal, ${ }^{2}$ Department of Biochemistry, KIST Medical Col- \\ lege, Lalitpur, Nepal, ${ }^{3}$ Department of Obstetrics and Gynaecology, KIST Medical College, Lalitpur, Nepal.
}

\begin{abstract}
Aims:This study evaluates the effectiveness of condom tamponade in the management of massive obstetric hemorrhage.
Methods: This hospital based prospective descriptive study was done in the department of obstetrics and gynecology of KIST Medical College Teaching Hospital, Lalitpur, Nepal from January 2013 to December 2013. During the study period, patients with obstetric hemorrhage $(>500 \mathrm{ml}$ blood loss) were identified and the details of the patient and their treatment were acquired. Data analysis was done by descriptive statistics using mean, median and frequency cross tabulations. The decision for condom tamponade was made when active continuous hemorrhage persisted despite of initial conservative measures.
\end{abstract}

Results: Among 39 patients of obstetric hemorrhage out of 1522 deliveries, eight were managed by condom tamponade which includes 6 postpartum hemorrhage cases, 1 incomplete abortion case and 1 antepartum case managed prophylactically in anticipation of postpartum hemorrhage.

Conclusions: Despite of the small study sample, the study concludes the use of condom tamponade as an effective means of controlling massive obstetrical hemorrhage due to uterine atony (both in post partum and post abortion cases). It is safe, easily available, inexpensive, minimally invasive, does not require anesthesia, easy to use and can be performed by any level of health personnel with some training.

Keywords: condom tamponade; obstetric hemorrhage; postpartum hemorrhage; uterine atony.

\section{INTRODUCTION}

Obstetric hemorrhage is the single most significant cause of maternal mortality worldwide accounting for $25-30 \%$ of all maternal deaths. ${ }^{1,2}$ Postpartum hemorrhage (PPH) is one major cause of maternal deaths worldwide. Nepal's estimated maternal mortality ratio (MMR) is 170 per 100,000 live births and $24 \%$ of these deaths are attributable to $\mathrm{PPH} .{ }^{3,4}$

The most common cause of PPH is uterine atony. A delay in correction of hypovolemia and delay in the control of bleeding are the main avoidable factors in most maternal deaths caused by hemorrhage. ${ }^{5}$ Whatever is the cause of $\mathrm{PPH}$, death due to this should be preventable and successful outcome is largely dependent upon timely interference and use of rapidly effective method. Active management of

\section{CORRESPONDENCE}

Dr. Bandana Sharma Gurung

Department of Obstetrics and Gynaecology

KIST Medical College, Lalitpur

Email: drbandanamd@gmail.com

Phone:+977-9841341744 the third stage of labor reduces uterine atony and is the mainstay of prevention of hemorrhage. ${ }^{6}$

At times PPH does not respond to commonly used first line pharmacologic measures like ergometrine, oxytocin, carboprost amd misoprostol. Bimanual compression, uterine packing, and surgical interventions such as B-Lynch suture, ${ }^{7,8}$ ligation of uterine artery, ovarian artery, and internal iliac artery, and embolization are effective methods for controlling intractable hemorrhage. Hysterectomy is the procedure of last resort to save patients' lives. ${ }^{9} 10$ After failed medical treatment, and before proceeding to major surgical intervention and possible hysterectomy, attempting to compress the uterine sinuses and to stop bleeding via intrauterine tamponade is a reasonable option for management of $\mathrm{PPH}$. Successful results have been shown in various researches by using a Sengstaken-Blakemore tube and a Rusch urologic hydrostatic balloon catheter to create intrauterine tamponade for treatment of atonic PPH. ${ }^{11,12}$ 
Recently uterine balloon tamponade in the management of PPH has been reported increasingly with success rates of over $84 \%$. A systematic review of conservative PPH management concluded that, it should be considered as a first step in the management of intractable $\mathrm{PPH}$, which is not due to genital trauma or retained tissue and which does not respond to uterotonics. ${ }^{13}$ A condom tied with a rubber catheter in the uterus and filled with saline to compress the uterine cavity can effectively control bleeding. It is a simple device and can be used even in low resource settings.

The purpose of this study is to evaluate the effectiveness of condom tamponade in the management of massive obstetric hemorrhage (postpartum, post abortion and antepartum) due to uterine atony and to share our initial experience of its use in KIST Medical College and Teaching Hospital (KISTMCTH).

\section{METHODS}

This hospital based prospective descriptive study was done in the department of obstetrics and gynecology of KIST Medical College and Teaching Hospital, a newly established tertiary care medical college situated in Lalitpur, Nepal. This hospital has been providing quality obstetric care right from the time of its establishment seven years ago. Because of its location at suburban area, it caters to the rural as well as urban women. The study period was from January to December, 2013.

We defined PPH estimated blood loss $>500 \mathrm{ml}$ after vaginal delivery or $>1000 \mathrm{ml}$ after cesarean section. ${ }^{6}$ Initial management of atonic PPH included resuscitative measures, correction of hypovolemia with intravenous fluid/blood transfusion, uterotonics, uterine massage and/or bimanual compression. In the majority of cases the decision for condom tamponade was made when active continuous hemorrhage persisted despite of these initial conservative measures. It was also used in the management of massive postabortion hemorrhage and as a prophylactic measure in anticipation of potential PPH in case of a severe antepartum hemorrhage due to placenta previa.

With aseptic precautions, a condom was rolled over a foley catheter (no. 20) and tied with a cotton thread on two sites $1 \mathrm{~cm}$ apart (Figure 1). The cervix was identified and the condom tamponade was introduced into the uterus manually. The condom was inflated with 100-300 $\mathrm{ml}$ warm saline with the help of a 50 $\mathrm{ml}$ syringe till bleeding ceased. The catheter was tightened by an umbilical clamp or cotton string and taped to the thigh. Vagina was loosely packed. Indwelling catheter was left in bladder till the condom tamponade was in place. Fundal height was marked on abdomen. Oxytocin drip (10-20 units in half litre DNS) was continued for at least 24 hours after the procedure. Broad spectrum antibiotics were also given prophylactically. Patients were watched for vital signs, pallor, rise in fundal height and bleeding per vagina. Condom tamponade was kept for 4872 hours and was deflated slowly after the patients remained stable. Bleeding per vagina and condition of uterus was noted. No patients required reinflation of balloon for recurrent bleeding.

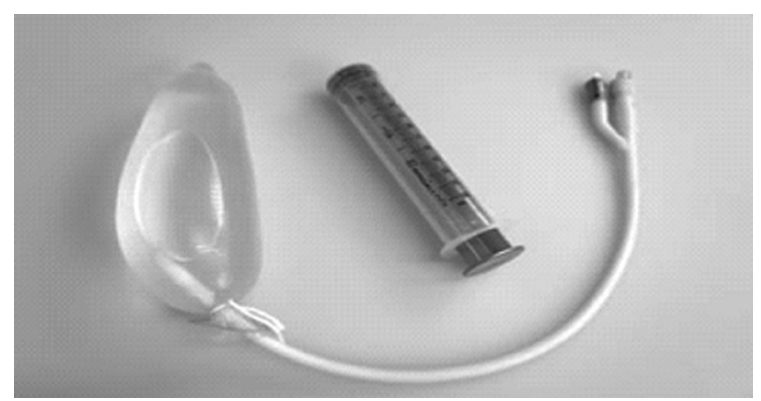

Figure 1. Condom Tamponade.

\section{RESULTS}

During the study period of one year, total number of delivery was 1522 . A total of $39(2.56 \%)$ women had massive obstetric hemorrhage i.e estimated blood loss $>1000 \mathrm{ml}$.

37 out of 39 obstetric hemorrhage cases were $\mathrm{PPH}$. Among the 39 cases of obstetric hemorrhage, 8 were managed by condom tamponade, which includes 6 PPH cases - 3 primary and 3 secondary; 1 incomplete abortion case of 10 weeks of gestation and 1 antepartum hemorrhage with placenta previa and hand prolapsed with intrauterine fetal death managed prophylactically.

The age of the patients ranged from 18-30 years, with the mean age 24.3 years. Parity ranged from 1-4, with a median of 2 and the gestational age ranged from $10-$ 41 weeks. Five patients had attended regular antenatal care. Majority of the patients had spontaneous vaginal 
delivery. 7 cases were therapeutically intervened and 1 was prophylactically managed. Majority of the patients developed PPH immediately after delivery. The patient characteristics are summarized in Table 1.

Table 1. Patient characteristics.

\begin{tabular}{|c|c|c|}
\hline \multicolumn{3}{|l|}{ General } \\
\hline Age & Range : $18-30$ years & Mean : 24.3 years \\
\hline Parity & Range : 1-4 & Median : 2 \\
\hline Gestational age & Range: $10-41$ weeks & \\
\hline $\begin{array}{l}\text { Type of ANC } \\
\text { Attendance }\end{array}$ & $\begin{array}{l}\text { Number of cases } \\
(n=8)\end{array}$ & Percentage \\
\hline Booked & 5 & $62.5 \%$ \\
\hline Unbooked & 3 & $37.5 \%$ \\
\hline Type of Labor & $\begin{array}{l}\text { Number of cases } \\
(n=7)\end{array}$ & Percentage \\
\hline $\begin{array}{l}\text { Induction of } \\
\text { labor }\end{array}$ & 1 & $14.3 \%$ \\
\hline Spontaneous & 6 & $85.7 \%$ \\
\hline $\begin{array}{l}\text { Type of } \\
\text { Intervention }\end{array}$ & $\begin{array}{l}\text { Number of cases } \\
(n=8)\end{array}$ & Percentage \\
\hline Therapeutic & 7 & $87.5 \%$ \\
\hline Prophylactic & 1 & $12.5 \%$ \\
\hline $\begin{array}{l}\text { Termination of } \\
\text { Pregnancy }\end{array}$ & $\begin{array}{l}\text { Number of cases } \\
(n=8)\end{array}$ & Percentage \\
\hline Abortion & 1 & $12.5 \%$ \\
\hline $\begin{array}{l}\text { Spontaneous } \\
\text { vaginal delivery }\end{array}$ & 6 & $75 \%$ \\
\hline $\begin{array}{l}\text { Instrumental/ } \\
\text { low forceps }\end{array}$ & 1 & $12.5 \%$ \\
\hline LSCS & 0 & $0 \%$ \\
\hline Type of PPH & $\begin{array}{l}\text { Number of cases } \\
(n=6)\end{array}$ & Percentage \\
\hline Primary & 3 & $50 \%$ \\
\hline Secondary & 3 & $50 \%$ \\
\hline $\begin{array}{l}\text { Place of } \\
\text { Delivery }\end{array}$ & $\begin{array}{l}\text { Number of cases } \\
(n=7)\end{array}$ & Percentage \\
\hline Hospital & 6 & $85.7 \%$ \\
\hline Outside hospital & 1 & $14.3 \%$ \\
\hline $\begin{array}{l}\text { Interval of } \\
\text { Delivery and } \\
\text { PPH }\end{array}$ & $\begin{array}{l}\text { Number of cases } \\
(n=6)\end{array}$ & Percentage \\
\hline Immediate & 3 & $50 \%$ \\
\hline $1-24 \mathrm{hrs}$ & 0 & $0 \%$ \\
\hline $24-48 \mathrm{hrs}$ & 2 & $33.3 \%$ \\
\hline$>48 \mathrm{hrs}$ & 1 & $16.7 \%$ \\
\hline
\end{tabular}

The predisposing factors and causes of $\mathrm{PPH}$ identified in this study were summarized in Table 2 .
Table 2. Predisposing factors and causes of hemorrhage.

\begin{tabular}{lll}
\hline $\begin{array}{l}\text { Predisposing } \\
\text { Factors }\end{array}$ & $\begin{array}{l}\text { Number of cases } \\
(\mathbf{n = 8})\end{array}$ & Percentage \\
\hline PIH & 1 & $12.5 \%$ \\
Post-term Pregnancy & 1 & $12.5 \%$ \\
Thrombocytopenia & 1 & $12.5 \%$ \\
APH/IUFD & 1 & $12.5 \%$ \\
None & 4 & $50 \%$ \\
$\begin{array}{l}\text { Causes of } \\
\text { Hemorrhage }\end{array}$ & $\begin{array}{l}\text { Number of cases } \\
(\mathbf{n}=7)\end{array}$ & Percentage \\
Atony & 3 & $42.85 \%$ \\
$\begin{array}{l}\text { Retained placental } \\
\text { tissue plus atony }\end{array}$ & 3 & $42.85 \%$ \\
$\begin{array}{l}\text { Coagulopathy } \\
\text { plus atony }\end{array}$ & 1 & $14.3 \%$ \\
\hline
\end{tabular}

Majority of the patients had unidentified predisposing factors with some identified factors such as pregnancy induced hypertension (PIH), post-term pregnancy, thrombocytopenia and antepartum hemorrhage/ intrauterine fetal death (APH/IUFD). The causes of hemorrhage generally included uterine atony, retained placental tissue and atony, and coagulopathy with atony.

Active management of the third stage of labor was practiced in all patients following delivery in the hospital. Uterotonics given before PPH was oxytocin and after PPH were oxytocin, methergin, carboprost and misoprostol. Condom catheter was placed within the first four hours with arrest of bleeding immediately after insertion in all the patients. The condom tamponade was kept in the uterus for 48 hrs in 7 patients and for 72 hrs in 1 patient. After the procedure vaginal packing was done loosely with gauze pad in all cases and removed within $24 \mathrm{hrs}$. Oxytocin was continued for at-least $12 \mathrm{hrs}$ following insertion of condom catheter. Broad spectrum antibiotics was prophylactically given in all cases. The saline needed to inflate the condom catheter in the majority was $300 \mathrm{ml}$. Blood loss in majority of cases was between 1000-2000 ml. Transfusion of blood and blood products was 2-12 units. Seven cases were in shock before management and were admitted to the intensive care unit (average stay 2 days) for close monitoring. None of the patients went into irreversible shock. There was no intrauterine infection documented by clinical signs and symptoms. All the patients of massive obstetric hemorrhage were successfully managed, the details of which is 
summarized in Table 3.

Table 3. Management of PPH.

\begin{tabular}{|c|c|c|}
\hline Management & $\begin{array}{l}\text { Number of cases } \\
(n=8)\end{array}$ & Percentage \\
\hline \multicolumn{3}{|c|}{ Introduction of Condom Tamponade } \\
\hline $\begin{array}{l}0-4 \mathrm{hrs} \text { of onset } \\
\text { of bleeding }\end{array}$ & All & $100 \%$ \\
\hline $5-24 \mathrm{hrs}$ & 0 & $0 \%$ \\
\hline $25-48 \mathrm{hrs}$ & 0 & $0 \%$ \\
\hline \multicolumn{3}{|c|}{ Arrest of Bleeding after Condom Tamponade } \\
\hline $\begin{array}{l}\text { Immediate } \\
(0-15 \text { minutes })\end{array}$ & All & $100 \%$ \\
\hline \multicolumn{3}{|c|}{ Condom Tamponade Kept for } \\
\hline $48 \mathrm{hrs}$ & 7 & $87.5 \%$ \\
\hline $72 \mathrm{hrs}$ & 1 & $12.5 \%$ \\
\hline \multicolumn{3}{|c|}{ Saline Needed to Inflate the Balloon } \\
\hline $100 \mathrm{ml}$ & 1 & $12.5 \%$ \\
\hline $200 \mathrm{ml}$ & 3 & $37.5 \%$ \\
\hline $300 \mathrm{ml}$ & 4 & $50 \%$ \\
\hline \multicolumn{3}{|l|}{ Time of Removal } \\
\hline $24 \mathrm{hrs}$ & 0 & $0 \%$ \\
\hline $48 \mathrm{hrs}$ & 7 & $87.5 \%$ \\
\hline $72 \mathrm{hrs}$ & 1 & $12.5 \%$ \\
\hline \multicolumn{3}{|l|}{ Blood Loss } \\
\hline $500-1000 \mathrm{ml}$ & 2 & $25 \%$ \\
\hline $1000-2000 \mathrm{ml}$ & 6 & $75 \%$ \\
\hline \multicolumn{3}{|c|}{ Blood Transfusion Needed (Units) } \\
\hline $1-5$ & 4 & $50 \%$ \\
\hline $6-9$ & 1 & $12.5 \%$ \\
\hline $10-12$ & 3 & $37.5 \%$ \\
\hline $\begin{array}{l}\text { Successful Management } \\
\text { of Obstetrical Hemorrhage }\end{array}$ & All & $100 \%$ \\
\hline $\begin{array}{l}\text { Intensive Care } \\
\text { Unit Management }\end{array}$ & 7 & $87.5 \%$ \\
\hline
\end{tabular}

\section{DISCUSSION}

$\mathrm{PPH}$ - a major composite of obstetric hemorrhageis ubiquitous as it can kill "even a healthy woman within two hours, if unattended" 2 and as well "a poor, malnourished, unhealthy woman delivering away from medical care". ${ }^{14}$ Despite its ubiquity, the root causes of PPH remain obscure, however, the four Ts (Tone, Trauma, Tissue and Thrombin) ${ }^{15}$ are considered the major factors resulting into the PPH. The inadequate uterine contraction, i.e, uterine atony, to sufficiently clamp the uterine vessels and stop bleeding ${ }^{16}$ - is the most common cause of PPH. It can lead to rapid and severe hemorrhage and hypovolemic shock. Lacerations and hematomas resulting from birth trauma can cause significant blood loss that can be lessened by hemostasis and timely repair. Retained tissue (placenta, placental fragments and blood clots) prevents the uterus from contracting enough to achieve optimal tone. ${ }^{15}$ The last and rare cause of PPH is due to coagulopathic bleeding before or during labor which can be the result of various clinical conditions such as HELLP (Hemolysis Elevated Liver enzymes and Low Platelets) syndrome or disseminated intravascular coagulation (DIC). Obstetric conditions that can cause DIC includes severe preeclampsia, amniotic fluid embolism, sepsis, placental abruption and prolonged retention of fetal demise. ${ }^{17}$

In a typical delivery, the placenta begins to separate from the uterine wall even before the delivery of the baby. The mechanical constriction of the blood vessels due to the uterine muscle contraction and retraction and by clots sealing off the raw surface in the placental bed usually stops uterine bleeding at the site of placental separation. ${ }^{18}$ Uterine contractions are promoted by the pituitary hormone oxytocin, whose release is stimulated by the stretching of the cervix and vaginal canal during birth and by nipple stimulation during lactation. ${ }^{19}$ Coagulation factors in the maternal blood contribute to the formation of clots that also stem the blood flow. ${ }^{20}$ The catastrophic hemorrhage is inevitable when these mechanisms are unable to stop the uterine bleeding.

At the end of normal pregnancy, the concentrations of several clotting factors increase and several of the natural anticoagulants, as well as fibrinolytic activity, decrease. These physiological changes result in an apparent hypercoagulability state described as a low-grade compensated DIC, which may be important for minimizing blood loss at delivery. ${ }^{21}$ During the first hours following delivery, a marked increase in clotting system activity and an increase in fibrinolytic activity have been reported. Several factors may favor postpartum DIC, including obstetrical complications such as abruptio placentae and amniotic fluid embolism. DIC may also be related to endothelial cell damage secondary to hemorrhagic shock. ${ }^{22}$ DIC is therefore a well-known phenomenon in the course of PPH. Hemostatic alterations could contribute to the severity of PPH and the early detection of these alterations could predict cases with more severe bleeding. Charbit et $\mathrm{al}^{23}$ in their study compared various hemostatic markers to predict the 
development and severity of the PPH. They found the levels of fibrinogen independently associated with the development of PPH and its severity. Fibrinogen concentration increases physiologically during pregnancy, but the study has shown that the fibrinogen concentrations were significantly lower in women who went on to develop PPH in comparison to women who did not. Besides, the decrease in fibrinogen level can be used as a significant indicator of severity of PPH in the hours to come. The decrease in fibrinogen concentration may result from several mechanisms such as qualitative or quantitative abnormalities in fibrinogen, and/or decrease in concentration of fibrinogen owing to hemodilution during the early phase of hemorrhage. ${ }^{23}$

Treatment strategy for PPH incorporates the techniques needed to control the bleeding and achieve hemostasis, such as pharmacological and medical intervention, packing or tamponade of uterine cavity and emergency surgery. The management varies greatly among the patients depending upon the etiology of the bleeding, available treatment options, and a patient's desire for future fertility. Medical management includes the administration of additional uterotonics such as prostaglandins and oxytocin as the first-line treatment for hemorrhage. Human recombinant factor VIIa has emerged as a new treatment modality which effectively controls severe, life-threatening hemorrhage by acting on the extrinsic clotting pathway. ${ }^{24}$

Surgical options for major PPH include uterine compression sutures, vessel ligation and hysterectomy. These procedures are invasive, involve laparotomy, require specialist expertise, may be associated with significant morbidity and may compromise future fertility. Interventional radiology offers a minimally invasive, fertility-preserving alternative but requires special equipment, trained interventional radiologists and is not readily available in most obstetric units.

Balloon tamponade two way catheter devices helps in controlling severe PPH and is especially applicable to atonic PPH cases following a vaginal delivery, those unresponsive to medical management, and before surgical interventions..$^{25}$ However, a balloon tamponade cannot stop bleeding from cervical lacerations. This device comprises of a "balloon" usually made of synthetic rubber balloon catheters such as Foley catheters, Rush catheters, SengstakenBlakemore and even using low-cost sterile rubber glove, condom, or other devices that is attached to a rubber urinary catheter and then inserted into the uterus under aseptic conditions. The "balloon" is attached to a syringe and filled with sufficient saline solution to exert enough counter-pressure to stop bleeding. The "balloon" is left in place for up to 24-48 hours, and it is gradually deflated and then removed. If bleeding starts again during the deflating period, the balloon is re-inflated. A balloon tamponade can stop bleeding in $77.5 \%$ to $88.8 \%$ cases without any further need for surgical treatment. ${ }^{14,26}$

Research shows that low-cost condom tamponade is a good alternative to standard balloon tamponades in resource poor settings. A systematic review of numerous studies on condom tamponade found that it was successful in treating 186 cases out of the total 193 cases. ${ }^{27}$ However, the process of inserting and inflating the condom catheter varied considerably - a few used forceps to insert the condom catheter into the uterus, and several used gravity inflation and an IV infusion set to inflate the condom instead of a syringe. A study has also been conducted in Nepal where all 14 PPH cases were successfully managed using condom tamponade. ${ }^{28}$ The authors of this study concluded that condom tamponade is an effective measure to control $\mathrm{PPH}$, and that it can be used effectively even by people with limited medical expertise. The availability of condoms free of cost at all the government health facilities further adds to the feasibility of expanding this intervention in Nepal. A $100 \%$ success rate has also been reported in an earlier study conducted in Bangladesh. ${ }^{29}$ The government of Bangladesh has introduced a training program for midwives and Family Health Workers to expand use of the condom catheters to primary health centers.

The World Health Organization (WHO), the International Federation of Gynecology and Obstetrics (FIGO), the American College of Obstetricians and Gynecologists (ACOG), the Royal College of Obstetricians and Gynecologists (RCOG), and the International Confederation of Midwives (ICM) recognizes balloon tamponade as a method that could have significant impact in the management of intractable PPH, especially in low resource areas 
where surgical interventions are not an option. ${ }^{14,24,30}$ The WHO has included balloon tamponade in their 2012 guidelines for the management of PPH - "The use of intrauterine balloon tamponade is recommended for refractory bleeding or if uterotonics are unavailable." ${ }^{\prime 30}$ PATH and HealthTech are currently in the process of developing an affordable balloon tamponade that costs less than $\$ 10$, compared to current models used in developed countries that cost between $\$ 77$ and $\$ 312 .{ }^{31}$

\section{CONCLUSIONS}

Although the sample size in our study was small, massive bleeding was controlled very quickly by inserting and inflating the condom. No patient required further intervention and there was no serious morbidity.

Uterine balloon tamponade (UBT) appeared to have great potential as an effective treatment for $\mathrm{PPH}$, is simple to use and appears to have low risk of harm. Further study of UBT interventions in resource poor settings can help to understand the barriers to its use and opportunities to reduce global maternal mortality. In remote areas where primary healthcare providers encounter atonic PPH this can be life saving and should be done even before referral to first referral unit, as many a times the patient is in irreversible shock by the time she reaches there.

\section{DISCLOSURE}

The authors report no conflicts of interest in this work.

No violation of human rights and safety.

Funding: Nil

\section{REFERENCES}

1. World Health Organisation (WHO). Maternal mortality in 2000: Estimates developed by WHO,UNICEF, and UNFPA,Geneva:WHO;2004 (Cited on March 25). Available from http://whqlibdoc.who.int/hq/2000/a81531. pdf

2. World Health Organisation (WHO). The World Health Report 2005: Make every mother and child count. Geneva, Switzerland: WHO Press;2005. (Cited on March 25). Available from http://www.who.int/whr/2005/en/index. html

3. World Health Organisation (WHO). Trends in Maternal Mortality: 1990 to 2010- WHO, UNICEF, UNFPA and the World Bank Estimates. Geneva: World Health Organization. 2012. (Cited of March 25, 2014). Available from https://www.unfpa.org/webdav/site/global/shared/
documents/publications/2012/Trends_in_maternal_ mortality_A4-1.pdf

4. Suvedi BK, Pradhan A . Nepal Maternal Mortality and Morbidity Study 2008/2009: Summary of Preliminary Findings. Kathmandu, Nepal. Family Health Division, Department of Health Services, Ministry of Health, Government of Nepal.

5. Maine D, Rosenfield A, Wallis M. Prevention of maternal death in developing countries. New York, NY:The Center for Population of Family Health; 1999.

6. Prendiville WJ, Elbourne D, McDonald S. Active vs expectant management of the third stage of labour (Cochrane Review). In: The Cochrane Library. Issue 3, 2000. Oxford: Update software.

7. Vangsgaard K. "B-Lynch-suture" in uterine atony. UgeshrLaeger. 2000; 162: 3468.

8. B-Lynch C, Coker A, Lawal AH, Abu J, Cowen MJ. The B-Lynch surgical technique for the control of massive postpartum haemorrhage: an alternative to hysterectomy? Five cases reported. Br J Obstet Gynaecol.

9. Stanco LM, Schrimmer DB, Paul RH, Mishell DR Emergency peripartum hysterectomy and associated risk factors. Am J Obstet Gynaecol. 1993;168: 879-83.

10. Abu-Heija AT, Jallad FF. Emergency peripartum hysterectomy at the Princess Badees Teaching Hospital in North Jordan. J Obstet Gynaecol Res. 1999; 25; 193-95.

11. Katesmark M, Brown R, Raju KS. Successful use of a Sengstaken-Blakemore tube to control massivepostpartum haemorrhage. Br. J Obstet Gynaecol. 1994; 101: 259-60.

12. Johanson RB, Kumar M, Obhrai M, Young P. Management of massive postpartum haemorrhage: use of a hydrostatic balloon catheter to avoid laparotomy. Br J Obstet Gynaecol. 2001; 108: 420-22.

13. Doumouchtsis SK, Papageorghiou AT, Arulkumaran S. Systematic review of conservative management of postpartum hemorrhage: What to do when medical treatment fails. Obstet Gynecol Survey. 2007: 62; 540-47.

14. Lalonde AB, Daviss B, Acosta A, Herschderfer $\mathrm{K}$ Postpartum Hemorrhage Today: ICM/FIGO Initiative 2004-2006. Int J Gynecol Obstet. 2006; 94(3): 243-53.

15. Evensen A, Anderson J. Chapter J: Postpartum hemorrhage: Third stage pregnancy. 2013: e1-e20. (Cited on April 4, 2014). Available from http://www.aafp.org/ dam/AAFP/documents/about_us/initiatives/also-blso/ also_syllabus/chapterj-postpartum-hemorrhage.pdf

16. Abrams E, Rutherford J. Framing postpartum hemorrhage as a consequence of human placental biology: An evolutionary and comparative perspective. Am Anthropol. 2011 September; $113(3): 417-430$

17. Richey ME, Gilstrap LC, Ramin SM. Management of disseminated intravascular coagulopathy. Clin Obstet Gynecol. 1995; 38: 514—520.

18. Choo WL, Chua S, Chong YS, Vanaja K, Oei P, Ho LM et al.Correlation of change in uterine activity to blood loss in the third stage of labour. Gynecol Obstet Invest. 1998; 46(3): $170-180$.

19. Christensson K, Nilsson BA, Stock S, Matthiesen AS, Uvnas-Moberg K. Effect of nipple stimulation in uterine activity and on plasma levels of oxytocin in full term, healthy, pregnant women. Acta Obstet et Gynecol Scand.1989; 68(3): 205-210. 
20. Martinelli I, Bucciarelli P, Mannucci PM. Thrombotic risk factors: Basic pathophysiology. Crit Care Med. 2010; 38(Supp 2): 3-9.

21. Brenner B. Hemostatic changes in pregnancy. Thromb Res. 2004; 114: 409—14

22. Kobayashi T, Terao T, Maki M, Ikenoue T. Diagnosis and management of acute obstetrical DIC. Semin Thromb Hemost. 2001; 27: 161—67.

23. Charbit B, Mandelbrot L, Samain E, Baron G, Haddaou $\mathrm{B}$, Keita $\mathrm{H}$ et al. for the PPH study group. The decrease of fibrinogen is an early predictor of the severity of postpartum hemorrhage. J Thromb Haemost. 2007; 5: $266-73$.

24. American College of Obstetric and Gynecology. ACOG Practice Bulletin: Clinical management guidelines for obstetrician-gynecologists No. 76: Postpartum hemorrhage. Obstet Gynecol. 2006; 108: 1039— 47 .

25. The Global Library of Women's Medicine 2012. A Comprehensive Textbook of Postpartum Hemorrhage 2nd Edition- An essential clinical reference for Effective Management. (Cited on March 25, 2014). Available at http://www.glowm.com/safer topic resources/profession/ topic/page/management postpartum hemorrhage. $\mathrm{html} /$ title/a-comprehensive-textbook-of-postpartumhemorrhage-2nd-edition/resource_doc/5935

26. Georgiou C. Balloon tamponade in the management of postpartum haemorrhage: a review. BJOG. 2009; 116(6): $748-57$.

27. Tindell K, Garfinkel R, Abu-Haydar E, Ahn R, Burke T, Conn $\mathrm{K}$ et al. Uterine balloon tamponade for the treatment of postpartum haemorrhage in resource-poor settings: a systematic review. BJOG. 2013; 120: 5-14.

28. Thapa K, Malla B. Intrauterine condom tamponade in management of postpartum haemorrhage. J Nepal Health Res Counc 2010; 8(16): 19-22.

29. Akhter S, Begum MR, Kabir Z. Use of a condom to control massive postpartum hemorrhage. MedGenMed. 2003. 11; 5(3): 38 .

30. World Health Organisation (WHO). WHO recommendations for the prevention and treatment of postpartum haemorrhage. 2009. (Cited on March 25, 2014). Available at http://apps.who.int/iris/ bitstream/10665/75411/1/9789241548502_eng.pdf

31. USAID. The Life-saving balloon: Developing an Affordable Post Partum Haemorrhage Treatment to Save Mothers' Lives. (Cited on March 25 2014). Available at http://www.usaid.gov/div/portfolio/life-saving-balloon 